\title{
TAKTYCZNA BROŃ NUKLEARNA W EUROPIE
}

Po zakończeniu zimnej wojny broń nuklearna została ,zdegradowana” z pozycji kluczowego czynnika w kształtowaniu międzynarodowego bezpieczeństwa do rangi zagadnienia ważnego, ale z pewnością nie pierwszoplanowego. Przypomina o swoim istnieniu przede wszystkim przy okazji programów proliferacyjnych pewnych państw lub ze względu na projekty w zakresie kontroli zbrojeń (projekty, co trzeba przyznać, albo bez większego znaczenia, albo bez szans na realizację). Broń nuklearna pojawia się tam jednak w wymiarze strategicznym. Tymczasem taktyczna broń nuklearna, chociaż w czasie zimnej wojny pod względem liczebnym była rodzajem dominującym, egzystuje na marginesie strategicznej refleksji. Można nawet powiedzieć, że stanowi zapomniany rodzaj broni.

Celem opracowania jest ukazanie znaczenia taktycznej broni nuklearnej w europejskich państwach NATO - zarówno znaczenia militarnego, jak i politycznego (w tym symbolicznego). Pojawia się wobec tego pytanie o przyszłość tej broni (chociaż jest to pytanie $\mathrm{z}$ gatunku prognostyki politologicznej, która $\mathrm{z}$ definicji jest zajęciem charakteryzującym się znaczną niepewnością). W myśl postawionej tezy, wobec minimalnego znaczenia militarnego, to właśnie znaczenie polityczne będzie decydować o przyszłości taktycznej broni nuklearnej (w tym kontekście należy zwrócić uwagę na ambiwalentną postawę decydentów politycznych, co szczególnie widoczne jest na przykładzie Niemiec), wespół z kwestiami budżetowymi (przede wszystkim zabezpieczeniem finansowania środków przenoszenia tej broni).

\section{DEFINICJA}

Kwestia precyzyjnego zdefiniowania pojęcia „taktyczna broń nuklearna” nie jest jednoznaczna. Generalnie możemy wyróżnić trzy sposoby definiowania. Żaden z nich nie jest doskonały, jednak przez takie łączone ujęcie możemy uzyskać w miarę precyzyjny obraz definiowanego pojęcia, zwłaszcza jeśli ,przykroimy” je do europejskich uwarunkowań geostrategicznych.

Pierwszy sposób definiowania odnosi się do charakterystyk technicznych broni. Mowa tu konkretnie o dwóch charakterystykach - zasiegu broni oraz mocy głowicy bojowej (Woolf, 2015: 7). W przypadku zasiegu jako granicę przyjmuje się $500 \mathrm{~km}$. Jest to granica dyskusyjna, gdyż broń krótkiego zasiegu, ale ulokowana blisko terytorium przeciwnika (np. na okrętach podwodnych), może mieć znaczenie strategiczne. Granica $500 \mathrm{~km}$ ma też generalnie zastosowanie do warunków euroatlantyckich i nie powinna być traktowana jako ogólna zasada dla całego świata. Geopolityka odległości w innych częściach świata jest zupełnie inna - np. w przypadku Izraela, gdzie 
broń o zasięgu do $500 \mathrm{~km}$ może z powodzeniem pełnić rolę strategiczną (Rühl, 2005: 11-12).

Moc głowicy jest jeszcze mniej precyzyjnym kryterium demarkacji. W niektórych przypadkach moc broni taktycznej i strategicznej zazębia się (np. jeden z wariantów taktycznej bomby lotniczej B-61 posiada głowicę o mocy $170 \mathrm{kt}$, podczas gdy jedna z wersji strategicznego pocisku manewrującego Tomahawk ma moc zaledwie $5 \mathrm{kt}$ - w tym przypadku reguła, wedle której moc głowicy broni taktycznej jest mniejsza niż w wypadku broni strategicznej ulega wręcz odwróceniu). Gdy więc zasięg broni może być pewnym indykatorem wskazującym, czy daną broń potraktować jako taktyczną, moc głowicy może pełnić taką rolę tylko „z grubsza” (w tym znaczeniu, że broń o bardzo dużej mocy, liczonej nie w kilotonach, ale w megatonach, nigdy nie jest traktowana jako taktyczna).

Drugi rodzaj definiowania jako kryterium przejmuje zadania, jakie wykonywać ma dany rodzaj broni nuklearnej. Broń taktyczna służy do porażenia celów militarnych na polu walki oraz na zapleczu przeciwnika (samo zaplecze jest pojęciem nieostrym - chodzi generalnie o te zasoby, które mają bezpośredni wpływ na rezultat bieżących operacji wojskowych, np. transport zaopatrzenia). Taktyczna broń nuklearna nie jest natomiast wykorzystywana do niszczenia strategicznej broni przeciwnika (np. silosów z międzykontynentalnymi pociskami balistycznymi) ani do realizacji uderzeń wymierzonych w potencjał demograficzny nieprzyjaciela (pod tym eufemistycznym określeniem kryją się ataki nuklearne na miasta).

Wedle trzeciego sposobu definiowania, taktyczna broń nuklearna to broń, której nie obejmują definicje broni strategicznej oraz pośredniej w istniejących systemach kontroli zbrojeń (Arbman, Thornton, 2003: 7). Zaznaczyć trzeba przy tym, że nie ma żadnego porozumienia, które odnosiłoby się do broni taktycznej i definiowałoby ją. Stąd więc kryterium negatywne - skoro inne, nietaktyczne rodzaje broni nuklearnej są zdefiniowane w traktatach, wszystko, co nie jest przez nie objęte, uznać można za broń taktyczna. Systemy kontroli zbrojeń jako kryterium definicyjne przyjmują przede wszystkim zasięg broni. Za broń strategiczną uznaje się broń o zasięgu międzykontynentalnym (w przypadku pocisków balistycznych bazowania lądowego oznacza to zasięg co najmniej $5500 \mathrm{~km}$ ) oraz broń wystrzeliwaną z okrętów podwodnych. Z kolei broń o zasięgu pośrednim, o której mówi traktat INF (ang. Treaty on Intermediate-range Nuclear Forces), to broń o zasięgu w przedziale między 500 a $5500 \mathrm{~km}$. To spojrzenie także jest nieco zawężające, gdyż po pierwsze, traktat ten dotyczy tylko broni bazowania lądowego, a po drugie, jego stronami są tylko dwa państwa - Stany Zjednoczone oraz Związek Radziecki (oraz Rosja, będąca jego prawnym sukcesorem).

Paul Schulte proponuje następującą ogólną definicję taktycznej broni nuklearnej, która w sposób adekwatny (choć miejscami dość ogólnikowy) opisuje jej specyfikę, przede wszystkim przez pryzmat zadań: „Taktyczna broń nuklearna to ładunki nuklearne oraz środki przenoszenia, charakteryzujące się stosunkowo niewielkim zasięgiem i stosunkowo niewielką mocą głowicy, przeznaczone do atakowania celów nuklearnych i konwencjonalnych (w tym środków transportu) na lądzie, morzu i w powietrzu, na polu walki oraz w ramach teatru działan. Zastosowanie tej broni ma stanowić element kampanii nuklearnej lub konwencjonalnej i nie jest ona przeznaczona do rażenia celów kluczowych ze strategicznego punktu widzenia w ramach sfery militarnej, eko- 
nomicznej lub politycznej przeciwnika. Użycie taktycznej broni nuklearnej może jednak stanowić niezawodny sygnał, że sytuacja jest postrzegana jako na tyle poważna, iż uzasadnia to przekształcenie konfliktu w konflikt nuklearny, ewentualnie kontynuowanie go jako konflikt nuklearny. Co za tym idzie, zastosowanie taktycznej broni nuklearnej oznacza ryzyko możliwej eskalacji konfliktu na poziom strategiczny" (Schulte, 2012: 15).

Podsumowując, za taktyczną broń nuklearną uznać można broń nuklearną charakteryzującą się ograniczonym zasięgiem (w euroatlantyckich warunkach geopolitycznych można przyjąc granicę $500 \mathrm{~km}$ ), ograniczoną mocą głowicy oraz specyficznym przeznaczeniem - służy ona do rażenia celów militarnych na polu walki oraz na zapleczu przeciwnika, wpływając bezpośrednio na przebieg bieżących operacji wojskowych.

\section{„WIELKI WYRÓWNYWACZ" - TAKTYCZNA BROŃ NUKLEARNA W CZASIE ZIMNEJ WOJNY}

Taktyczna broń nuklearna w czasie zimnej wojny pod względem liczebnym była dominujacym rodzajem broni nuklearnej. W państwach NATO miała ona służyć jako substytut sił konwencjonalnych i remedium na konwencjonalna, przede wszystkim ilościową, przewagę Układu Warszawskiego. Wedle słów Lesa Aspina, sekretarza obrony Stanów Zjednoczonych w latach 1993-1994, broń nuklearna stanowiła rodzaj wielkiego wyrównywacza (ang. great equalizer), gdyż „nasz główny przeciwnik posiadał w Europie siły konwencjonalne, które miały przewagę liczebną w stosunku do sił zachodnich" (cytat za: Millot, 1997: 459). Warto zaznaczyć, że wedle amerykańskiej tradycji określenie ,wielki wyrównywacz” kojarzone jest z rewolwerem Colta, który tak właśnie był potocznie nazywany w XIX wieku. Broń ta bowiem wyrównywała szanse przeciwników w pojedynku - siła fizyczna przestawała mieć decydujące znaczenie - i unieważniała wartość dotychczasowych atrybutów przewagi. Taką samą rolę pełnić miała taktyczna broń nuklearna powodując, że przewaga Układu Warszawskiego na polu sił konwencjonalnych przynajmniej w pewnym stopniu była podważona. Taka droga do wyrównania konwencjonalnej potęi Układu Warszawskiego traktowana była jako rozwiązania optymalne z punktu widzenia relacji koszt/efekt, gdyż koszt wyprodukowania taktycznego arsenału jądrowego był zdecydowanie niższy w stosunku do kosztu wyprodukowania takiej ilości broni konwencjonalnej, by zniwelować przewagę bloku wschodniego (Weitz, 2012: 9).

Taktyczną broń nuklearną traktowano również jako narzędzie kontrolowanej eskalacji konfliktu. Zakładano, że jej użycie będzie wiązało się z mniejszym ryzykiem przerodzenia się konfliktu w globalną wojnę nuklearną niż miałoby to miejsce w przypadku zastosowania broni strategicznej. Takie spojrzenie było zgodne $\mathrm{z}$ duchem tzw. konwencjonalizacji, która zakładała postrzeganie pewnych rodzajów broni masowego rażenia (przede wszystkim właśnie taktycznej broni nuklearnej) w sposób podobny jak traktowano broń konwencjonalną (Kamieński, 2009: 333). W zamyśle miało to uczynić wojnę nuklearną na powrót „możliwą do wyobrażenia” tak, by można było rozpatrywać ją w kategoriach ewentualnego zwycięstwa lub porażki, a nie tylko w kategoriach katastrofy dla ludzkości i planety. Takie podejście, zaproponowane przez Johna Fostera 
Dullesa, sekretarza stanu w gabinecie prezydenta USA Dwighta Eisenhowera, zakładało zróżnicowanie charakteru broni nuklearnej tak, by możliwe było użycie pewnych jej rodzajów bez następstw w postaci masowych ofiar i zniszczeń (Tannenwald, 2007: 176). Tego typu broń powinna być więc traktowana podobnie jak broń konwencjonalna (stąd termin konwencjonalizacja), a nie jak broń masowego rażenia, więc koszty polityczne i moralne jej zastosowania powinny być porównywalne raczej do kosztów użycia broni konwencjonalnej, a nie strategicznej broni nuklearnej.

Taktyczna broń nuklearna miała też być potencjalnie bardziej użyteczną w sensie czysto militarnym względem broni strategicznej, która była przede wszystkim narzędziem politycznym i w myśl koncepcji odstraszania udowadniała swoją przydatność tak długo, jak nie było konieczności jej stosowania. To mogło oznaczać większą skłonność do zastosowania taktycznej broni nuklearnej w przypadku wybuchu konfliktu zbrojnego. W tym sensie stanowiła ona częściową odpowiedź na kluczowy dylemat dotyczący nuklearnego odstraszania: jak zapewnić przeciwnika o realności naszej groźby w sytuacji, gdy perspektywa jej zrealizowania, ze względu na przerażające skutki, jest trudna do wyobrażenia. Nuklearne odstraszanie (tzw. odstraszanie oparte na karze - karą w tej sytuacji są same skutki użycia broni nuklearnej i dosiega ona w tym samym stopniu atakującego i broniącego się) obarczone jest ,skazą" polegającą na tym, że im surowsza groźba (trudno wyobrazić sobie surowszą niż uderzenie nuklearne) tym mniejsze prawdopodobieństwo jej urzeczywistnienia (Kopeć, 2014: 212). Biorąc pod uwagę, że odstraszanie w ogóle, a odstraszanie nuklearne w szczególności, jest przede wszystkim rodzajem strategii komunikacyjnej, taktyczna broń nuklearna była sposobem na urealnienie nuklearnej groźby.

Szczególnie symptomatyczny był pod tym względem przykład francuskiej taktycznej broni nuklearnej. Pierwszą generację tego typu uzbrojenia stanowiły rakiety Pluton, wprowadzone do uzbrojenia w 1974 roku. Zasadniczą rolą tej broni była kontrolowana eskalacja konfliktu w Europie Zachodniej (Laird, 2000: 12). W interesie Francji było bowiem stosunkowo szybkie przekroczenie progu nuklearnego w przypadku wybuchu konfliktu ze Związkiem Radzieckim i jego satelitami (Tertrais, 2004: 77-81). Francuzi nie widzieli bowiem szans na powstrzymanie konwencjonalnej ofensywy Układu Warszawskiego siłami europejskich członków NATO. Kontrolowane zastosowanie broni nuklearnej jawiło się po pierwsze, jako szansa na powstrzymanie pancernych zagonów ZSRR, po drugie, zwiększało prawdopodobieństwo aktywnego włączenia się do wojny Stanów Zjednoczonych. Francuzi obawiali się bowiem, że jeśli konflikt pozostanie na poziomie konwencjonalnym, USA zgodnie z doktryną elastycznego reagowania nie uznają za adekwatne włączenie się do działań zbrojnych na pełną skalą i zaoferują Europie Zachodniej tylko ograniczoną, czyli w domyśle niewystarczająca, pomoc (Kuźniar, 2005: 154). Szybka nuklearyzacja konfliktu miała być więc czynnikiem motywującym USA do zaangażowania się weń w pełnym wymiarze.

Warto zaznaczyć, że kwestia rozwoju i potencjalnego zastosowania francuskiej taktycznej broni nuklearnej stała się źródłem poważnych napięć w stosunkach z Republiką Federalną Niemiec. Berlin bowiem, nie bez racji, zakładał że to właśnie terytorium Niemiec stanie się jedną z głównych aren, gdzie broń ta będzie zastosowana. Niechybnie oznaczałoby to ogromne zniszczenia na terytorium tego państwa. Pod presją niemiecką i w obliczu zakończenia zimnej wojny rakiety o zasięgu taktycznym wy- 
strzeliwane z mobilnych wyrzutni lądowych calkowicie znikły z francuskich arsenałów nuklearnych jako kategoria broni. Chociaż kolejna generacja rakiet taktycznych (rakiety Hades) została opracowana w drugiej połowie lat 80., to w 1991 roku rząd ogłosił, że nie zostaną one wprowadzone do służby operacyjnej, ale będą składowane jako rezerwa, na wypadek wzrostu napięcia, w Luneville (20-25 rakiet). 23 lutego 1996 r. ogłoszono nowy kształt francuskich sił nuklearnych, i zabrakło w nim miejsca dla rakiet Hades, które postanowiono rozmontować. Ostatnią rakietę zniszczono 23 czerwca 1997 roku (Laird, 2000: 20-24). Sprawa wpływu taktycznej broni nuklearnej na relacje na linii Berlin-Paryż jest o tyle znamienna, że w pewnym stopniu thumaczy ambiwalentny stosunek Niemiec do NATO-wskiej taktycznej broni nuklearnej.

\section{NUCLEAR SHARING}

Zakończenie zimnej wojny zapoczątkowało okres gwałtownej redukcji arsenałów taktycznej broni nuklearnej w państwach NATO. W Stanach Zjednoczonych pozostało na uzbrojeniu około 760 sztuk taktycznej broni nuklearnej (są to dane szacunkowe, gdyż tego rodzaju broni nie obejmują porozumienia rozbrojeniowe, które obligowałyby do ujawniania dokładnego stanu arsenałów), w tym do 200 bomb lotniczych B-61 zmagazynowanych w Europie (Woolf, 2015: II). Wycofano m.in. nuklearną amunicję artyleryjską oraz rakiety zdolne do przenoszenia głowic nuklearnych - balistyczne MGM-52 Lance i przeciwlotnicze MIM-14 Nike Hercules. W ostatnich latach wycofano także broń taktyczną z pokładów okrętów - chodzi o pociski manewrujące BGM-109 Tomahawk w wersji TLAM/N (Tomahawk Land Attack Missile/Nuclear) przenoszone przez okręty nawodne US Navy. Decyzję podjęto w 2010 roku, a rakiety wycofano najprawdopodobniej do 2013 r. - instrukcja departamentu Marynarki Nuclear Weapons Responsibilities and Authorities z 2010 r. zawierała rozdział o nuklearnych Tomahawkach, a jej następna edycja z 2013 r. jest go pozbawiona (Kristensen, 2013). Również Wielka Brytania wycofała z uzbrojenia własną broń taktyczną - bomby lotnicze WE.177 znajdujące się na wyposażeniu Royal Navy do 1992 r. oraz Royal Air Force do 1998 r. (Childs, 2012: 312) - opierając swój arsenał nuklearny tylko na jednym rodzaju broni strategicznej - rakietach balistycznych Trident wystrzeliwanych z okrętów podwodnych typu Vanguard (Norris, Arkin, 2000: 70). Francja zrezygnowała z operacyjnego rozmieszczenia rakiet Hades, pozostawiając jednak pociski manewrujące wystrzeliwane z samolotów sił powietrznych i marynarki, będące pod względem konstrukcyjnym bronią taktyczną, chociaż przeznaczone są do realizacji nieco odmiennych zadań.

USA jest jedynym państwem nuklearnym, które posiada broń nuklearną rozmieszczoną na terytorium państw nienuklearnych (razem broń nuklearna jest obecna na terytorium 14 państw). W ramach mechanizmu nuclear sharing (nuklearnego współdzielenia) pięć państw NATO - Belgia, Holandia, Niemcy, Włochy i Turcja (czyli państwa formalnie nienuklearne) - utrzymuje nuklearne porozumienia ze Stanami Zjednoczonymi (Czulda, 2013: 55). Zakładają one stacjonowanie amerykańskiej broni nuklearnej (stanowi ona własność USA) na terytorium tych państw, a także możliwość przekazania im w czasie wojny kontroli nad bronią nuklearną. Zakres omawianego me- 
chanizmu uległ w ostatnich latach pewnemu zawężeniu - wcześniej w jego ramach funkcjonowała także Grecja (broń nuklearną wycofano $\mathrm{z}$ tego państwa w 2001 roku z powodu rażących naruszeń zasad bezpieczeństwa) oraz Wielka Brytania (która poza tym utrzymywała, i nadal utrzymuje własne, obecnie wyłącznie już strategiczne, siły nuklearne). W czasie zimnej wojny skala nuklearnego współdzielenia, dotyczącego nie tylko broni amerykańskiej, ale i brytyjskiej oraz radzieckiej, była zdecydowanie większa.

Tabela 1

Rozmieszczenie broni nuklearnej poza terytorium państwa-właściciela

\begin{tabular}{|c|c|c|}
\hline $\begin{array}{c}\text { Państwo będące } \\
\text { wlaścicielem broni }\end{array}$ & Państwo goszczące & Okres funkcjonowania \\
\hline \multirow[t]{14}{*}{ Stany Zjednoczone } & Belgia & od 1963 \\
\hline & Dania & $1958-1965$ \\
\hline & Filipiny & $1957-1977$ \\
\hline & Grecja & $1960-2001$ \\
\hline & Hiszpania & $1958-1976$ \\
\hline & Holandia & od 1960 \\
\hline & Kanada & 1964-1984 \\
\hline & Korea Płd. & $1958-1991$ \\
\hline & Maroko & $1953-1961$ \\
\hline & Niemcy & od 1955 \\
\hline & Tajwan & $1958-1974$ \\
\hline & Turcja & od 1959 \\
\hline & Wielka Brytania & $1954-2006$ \\
\hline & Włochy & od 1957 \\
\hline \multirow[t]{3}{*}{ Wielka Brytania } & Cypr & $1960-1975$ \\
\hline & Niemcy & $1972-1998$ \\
\hline & Singapur & $1962-1970$ \\
\hline \multirow[t]{6}{*}{ Związek Radziecki } & Czechosłowacja & $1965-1990$ \\
\hline & Kuba & 1962 \\
\hline & Mongolia & $1967-1992$ \\
\hline & Niemiecka Republika Demokratyczna & $1958-1991$ \\
\hline & Polska & $1969-1990$ \\
\hline & Węgry & 1974-1989 \\
\hline
\end{tabular}

Źródło: T. S. Sechser (2015), Sharing the Bomb: Nonproliferation, Deterrence, and Foreign Nuclear Deployments, University of Virginia, Charlottesville, s. 6.

Obecnie (stan na rok 2015) w Europie przechowywanych jest około 160-200 sztuk (dokładne dane nie są ujawniane) amerykańskiej taktycznej broni nuklearnej w postaci bomb lotniczych B-61 (Woolf, 2015: 18). Większość państw, na terytorium których rozmieszczono tę broń, posiada własne samoloty przystosowane do jej przenoszenia (wyjątkiem jest Turcja). Samoloty te określane są mianem DCA (ang. Dual Capable Aircraft - samolot podwójnego zastosowania, przystosowany do przenoszenia broni 
konwencjonalnej i nuklearnej). Turcja nie posiada własnych samolotów DCA, na jej terytorium nie stacjonują też samoloty amerykańskie przeznaczone do realizacji misji nuklearnych. Prawdopodobnie samoloty tureckie ćwicząjedynie eskortowanie samolotów DCA innych państw NATO (Stein, 2012: 4).

Tabela 2

Nuclear sharing w ramach NATO

\begin{tabular}{|l|l|c|l||}
\hline \multicolumn{1}{|c|}{ Państwo } & \multicolumn{1}{c|}{ Baza } & Liczba bomb & \multicolumn{1}{c|}{ Samoloty DCA } \\
\hline Niemcy & Fliegerhorst Büchel & $10-20$ & Tornado IDS \\
\hline Belgia & Kleine Brogel & $10-20$ & F-16AM/BM \\
\hline Holandia & Uden Volkel & $10-20$ & F-16AM/BM \\
\hline Włochy & Aviano & ok. 50 & F-16C (amerykańskie) \\
\cline { 2 - 4 } & Ghedi Torre & $10-20$ & Tornado IDS \\
\hline Turcja & Incirlik & $60-70$ & brak \\
\hline
\end{tabular}

Źródło: G. Neuneck (2012), European and German Perspectives, w: Tactical Nuclear Weapon and NATO, (eds.) T. Nichols, D. Stuart, J. D. McCausland, U.S. Army War College, Carlisle, s. 262.

Broń składowana w Europie w ramach programu nuclear sharing kontrolowana jest przez system Weapons Storage and Security System (WS3). Jego operatorem są amerykańskie siły powietrzne (Antony, Janssen, 2010: 16).

\section{PRZYPADEK SZCZEGÓLNY - FRANCJA}

Podstawą francuskiego arsenału nuklearnego są cztery strategiczne okręty podwodne Le Triomphant z pociskami balistycznymi M45 i M51. Oprócz tego Francja dysponuje bronią, którą z racji parametrów potraktować można jako taktyczną. Są to pociski powietrze-ziemia przenoszone przez samoloty sił powietrznych i marynarki wojennej. Pociski ASMP (fr. Air-Sol Moyenne Portée) zastąpiły używane wcześniej bomby AN-22 i AN-52. Od 2009 roku wprowadzany jest pocisk ASMP-A (fr. Air-Sol Moyenne Portée Amélioré, pocisk powietrze-ziemia średniego zasiegu-udoskonalony), charakteryzujący się m.in. większym zasięgiem. Nosicielami pocisków są w ramach sił powietrznych samoloty Mirage $2000 \mathrm{~N}$ oraz ich następcy Rafale F3, natomiast w marynarce wojennej samoloty pokładowe Super Etendard (mają być wycofane do 2016 roku) oraz nowe Rafale $M$ (Narang, 2014: 170).

Zadania tej broni są nietypowe, i z tego punktu widzenia należy zaliczyć ją raczej do broni substrategicznej, a nie taktycznej. Francuskie pociski mają bowiem posłużyć do przeprowadzenia ograniczonego ataku na wybrany obiekt w celu zademonstrowania determinacji w obronie żywotnych interesów (tzw. ostatnie ostrzeżenie). Z tego powodu atak ma wiązać się ze stosunkowo niewielkimi zniszczeniami, choć fakt użycia broni nuklearnej ma podkreślić "wymowę" tego gestu i powagę sytuacji. Uderzenie ostrzegawcze ma skłonić przeciwnika do zaniechania agresywnych działań. Stanowić ma ono komunikat zapowiadający odwet na pełną skalę (z użyciem pocisków balistycznych) w przypadku kontynuacji niepożądanych posunięć (Boniface, 1998: 19-20). 
Koncepcja „ostatniego ostrzeżenia” jest próbą osiagnięcia kompromisu między potrzebą uniknięcia sytuacji braku opcji poniżej progu nuklearnego (widoczna jest analogia z amerykańskimi rozważaniami na temat niedoskonałości doktryny zmasowanego odwetu) a niechęcią do adaptacji strategii elastycznego reagowania, postrzeganej jako niewystarczająco wiarygodna (Tertrais, 2007: 5). W obecnych warunkach bezpieczeństwa tradycyjna koncepcja odstraszania jest postrzegana jako wciąż relewantna, nawet w większym stopniu niż w czasie zimnej wojny, gdyż nowe potęgi regionalne mogą być $\mathrm{w}$ większym stopniu niezdolne do oszacowania francuskiej determinacji w ochronie żywotnych interesów niż był Związek Radziecki. Pozostaje jednak pytanie, czy w przypadku scenariusza innego niż atak na pelną skalą na francuskie terytorium (czyli np. szantaż z użyciem broni masowego rażenia czy też wspieranie organizacji terrorystycznej realizującej atak na cele we Francji) wystosowanie tego typu nuklearnego ostrzeżenia będzie adekwatne.

\section{OBECNE ZNACZENIE MILITARNE I POLITYCZNE}

Obecne znaczenie militarne taktycznej broni nuklearnej znajdującej się $\mathrm{w}$ arsenałach na terytorium europejskich państw NATO (przede wszystkim w ramach nuclear sharing) jest minimalne. Trudno wyobrazić sobie jej użycie z dwóch powodów. Pierwszym z nich są charakterystyki taktyczno-techniczne tej broni. B-61 jest bombą grawitacyjną opadającą na spadochronie (zastosowano go, by opóźnić opadanie i dać załodze samolotu czas na wyjście ze strefy rażenia). Wymaga ona przełamania nieprzyjacielskiej obrony powietrznej, przez co jej użycie jest niebezpieczne, ryzykowne i skomplikowane. Do realizacji opcji nuklearnej są bardziej dogodne narzędzia. Realizowana modernizacja bomby i doprowadzenie jej do standardu B-61-12 (obecnie w Europie zlokalizowane są bomby w wersjach B-61-3 i B-61-4; w służbie znajdują się ponadto wersje B-61-10, B-61-11 oraz wariant strategiczny o znacznie większej mocy B-61-7) niewiele zmienia. Zakłada ona bowiem przede wszystkim przekształcenie B-61w amunicję korygowaną za pomocą systemu nawigacji satelitarnej, co zdecydowanie zwiększy celność, ale nie zmieni zasadniczo ryzykownego sposobu ataku (Wilson, 2014: 262-263).

Tabela 3

Wersje bomby B-61

\begin{tabular}{|c|c|c|c|c|}
\hline Wariant & Moc glowicy [kt] & Nosiciele & Przeznaczenie & Uwagi \\
\hline 1 & 2 & 3 & 4 & 5 \\
\hline B-61-3 & $\begin{array}{l}\text { Regulowana: } \\
0,3 ; 1,5 ; 60 ; 170\end{array}$ & $\begin{array}{c}\mathrm{F}-15 \mathrm{E}, \mathrm{F}-16 \mathrm{~A} / \mathrm{B} / \mathrm{C} / \mathrm{D}, \\
\text { Tornado IDS }\end{array}$ & Taktyczne & $\begin{array}{l}\text { Wykorzystywane w ramach nuc- } \\
\text { lear sharing. }\end{array}$ \\
\hline B-61-4 & $\begin{array}{l}\text { Regulowana: } \\
0,3 ; 1,5 ; 10 ; 50\end{array}$ & $\begin{array}{c}\mathrm{F}-15 \mathrm{E}, \mathrm{F}-16 \mathrm{~A} / \mathrm{B} / \mathrm{C} / \mathrm{D}, \\
\text { Tornado IDS }\end{array}$ & Taktyczne & $\begin{array}{l}\text { Wykorzystywane w ramach nuc- } \\
\text { lear sharing. }\end{array}$ \\
\hline B-61-7 & $\begin{array}{l}\text { Regulowana: } \\
10-360\end{array}$ & $\mathrm{~B}-2 \mathrm{~A}, \mathrm{~B}-52 \mathrm{H}$ & Strategiczne & \\
\hline B-61-10 & $\begin{array}{l}\text { Regulowana: } \\
0,3 ; 5 ; 10 ; 80\end{array}$ & $\begin{array}{c}\mathrm{F}-15 \mathrm{E}, \mathrm{F}-16 \mathrm{~A} / \mathrm{B} / \mathrm{C} / \mathrm{D}, \\
\text { Tornado IDS }\end{array}$ & Taktyczne & Nieaktywne, w magazynach. \\
\hline
\end{tabular}




\begin{tabular}{||c|c|c|c|c||}
\hline 1 & 2 & 3 & 4 & 5 \\
\hline B-61-11 & 400 & B-2A & Strategiczne & \\
\hline B-61-12 & $\begin{array}{c}\text { Regulowana: } \\
0,3 ; 1,4 ; 10 ; 50\end{array}$ & F-15E, F-35, B-2A & Taktyczne & $\begin{array}{l}\text { Wersja naprowadzana. Proces roz- } \\
\text { wojowy w toku. Pierwszy test (bez } \\
\text { detonacji, przede wszystkim } \\
\text { sprawdzenie systemu naprowa- } \\
\text { dzania) 20 października 2015 r. }\end{array}$ \\
\hline
\end{tabular}

Źródlo: B-6I (2013), Global Security, http:/www.globalsecurity.org/wmd/systems/b61.htm, 25.01.2016; R. Czulda (2013), Taktyczna broń jadrowa w Europie, „Nowa Technika Wojskowa”, nr 6, s. 60.

Po drugie, ewentualne zastosowanie broni nuklearnej, nawet w wymiarze taktycznym, oznaczałoby złamanie tzw. nuklearnego tabu. Zakłada ono istnienie w ramach wspólnoty międzynarodowej nieformalnej normy zakazującej używania broni nuklearnej w sytuacji innej niż bezpośrednie zagrożenie egzystencji państwa i społeczeństwa. Norma ta powstrzymuje państwa od wykorzystania opcji nuklearnej, nawet jeśli z czysto militarnego punktu widzenia byłoby to uzasadnione (Tannenwald, 2007). Obawa przed złamaniem tej normy, oprócz problemów technicznych, była przyczyną wycofania się Stanów Zjednoczonych z programu penetratora nuklearnego małej mocy (ang. Nuclear Earth Penetrator Weapon), realizowanego w pierwszych latach ubiegłej dekady. W pewnym sensie (raczej konstrukcyjnym niż z punktu widzenia przeznaczenia) też byłaby to broń o charakterze taktycznym z tym, że jej głównym zadaniem miała być eliminacja podziemnych instalacji, związanych np. z produkcją broni masowego rażenia. Liczono, że ograniczenie skutków ubocznych dzięki zdolności do tzw. wybuchu zakrytego, czyli niepowodującego wydostawania się produktów eksplozji na powierzchnię, spowoduje iż broń tę będzie można stosować w konfliktach regionalnych przy akceptowanych kosztach politycznych. Ostatecznie uznano jednak, że broń nuklearna powinna powrócić do swej pierwotnej roli, czyli stać się tylko i wyłącznie narzędziem odstraszania, a dążenia w kierunku nadania jej charakteru użytecznego militarnie narzędzia opierają się na błędnej kalkulacji politycznej (Medalia, 2006: 20). Podobnie trudno wyobrazić sobie użycie taktycznej broni nuklearnej znajdującej się w arsenałach NATO w sytuacji innej niż ekstremalna. Wtedy jednak jakiekolwiek zastosowanie broni nuklearnej nabiera wymiaru strategicznego i sensu utrzymywania w linii broni taktycznej, generalnie dość przestarzałej i o ograniczonych możliwościach, z czysto militarnego punktu widzenia nie daje się obronić.

Argument, iż taktyczna broń nuklearna w ramach nuclear sharing jest kluczowa dla wiarygodności tzw. odstraszania rozszerzonego (Anderson, Larsen, Holdorf, 2013: 136-137), czyli parasola nuklearnego rozpostartego przez Stany Zjednoczone nad europejskimi sojusznikami, był niejednokrotnie podważany. W tym kontekście przede wszystkim przywoływana jest sytuacja sojuszników USA w basenie Pacyfiku. Stany Zjednoczone utrzymują przecież parasol nuklearny nad Australią, Japonią i Koreą Południową bez konieczności rozmieszczenia na ich terytorium broni nuklearnej - w tym ostatnim państwie amerykańska broń była rozmieszczona do 1991 roku, w pozostałych nigdy jej nie było (Kamp, Remkes, 2011: 77).

Taktyczna broń nuklearna ma jednak niebagatelne znaczenie polityczne. W czasie zimnej wojny program nuclear sharing miał za zadanie wyciszyć nuklearne ambicje europejskich członków NATO (Kristensen, Mount, 2014). Po pierwsze, stanowił on 
element nuklearnego parasola, jaki Stany Zjednoczone rozpostarły nad europejskimi członkami Sojuszu Północnoatlantyckiego, po drugie, części państw - aktywnie partycypującym w programie nuklearnego współdzielenia - oferował on iluzję posiadania własnej broni nuklearnej.

Obecnie nuclear sharing to przede wszystkim oznaka transatlantyckiej solidarności i amerykańskiego zaangażowania w Europie (Pifer, 2011: 25). W tym kontekście przywoływana jest nawet metafora nuclear sharing w NATO jako obrączki w małżeństwie (Murdock, Yeates, 2009: 31). Dla państw uczestniczących w programie, to również symbol specjalnego znaczenia w ramach NATO. Czynnik ten jest znaczący szczególnie w przypadku Turcji (Ingram, Kimball, Meier, 2011: 3). Dla Turcji obawa o wycofanie amerykańskich bomb nuklearnych jest jednoznaczna w obawą o obniżenie pozycji tego państwa w NATO. Wątpliwości Turcji dotyczą generalnie całego zaangażowania w Artykuł V i odnoszą się do rezerwy, z jaką inne państwa powitały Turcję w NATO, uważając że ma ona odmienne priorytety (związane raczej z sytuacją na Bliskim Wschodzie, a nie z obawą przed Związkiem Radzieckim) i może wciągnąc sojusz w niechcianą bliskowschodnią wojnę, a przynajmniej odciagnąc go od głównego wysiłku w kierunku przeciwstawienia się ZSRR. Ostatecznie jednak presja USA zdecydowała, że Turcja weszła do sojuszu w 1952 r. Wątpliwości Turcji narastały po wycofaniu amerykańskich rakiet Jupiter z jej terytorium czy po konflikcie z Grecją, kiedy USA nałożyły sankcje na sprzedaż broni. Dlatego też przez cały okres członkostwa, Turcja prezentowała proaktywną postawę, niejako wymuszając potwierdzenie zaangażowania innych państw, np. poprzez żądania rozmieszczenia na jej terytorium systemów przeciwlotniczych Patriot należących do państw sojuszniczych (np. Niemiec, Holandii) w sytuacji wzrostu napięcia na Bliskim Wschodzie (Stein, 2012: 2). Obecnie więc ewentualna rezygnacja z nuclear sharing mogłaby wręcz być zarzewiem debaty o zasadność członkowstwa Turcji w NATO (Kibaroglu, 2011: 33).

\section{PERSPEKTYWY NUCLEAR SHARING}

Jeszcze kilka lat temu przeważały głosy podważające sensowność kontynuowania programu nuclear sharing. Pochodziły one zarówno z Europy, jak i Stanów Zjednoczonych. Szczególnie aktywni na polu negowania zasadności nuclear sharing byli politycy niemieccy, m.in. minister obrony Peter Struck oraz szefowie dyplomacji Frank-Walter Steinmeier (Maettig, 2008) i Guido Westerwelle, który uznał go za ,relikt zimnej wojny bez militarnego znaczenia" (cytat za: Faradori, 2013: 4). Z powodu niechęci europejskich sojuszników także w Stanach Zjednoczonych kontestowano zasadność programu, który sprowadza się do tego, że USA za własne pieniądze przyczynia się do wzmocnienia europejskiego bezpieczeństwa i zamiast wdzięczności spotyka się jedynie $z$ niechęcią (Czulda, 2014: 92-93). Rozważano m.in. opcję okrojenia programu do jednego-dwóch państw, w których sensowność programu nie jest w takim stopniu podważana (np. Turcji i Włoch).

Kolejnym argumentem przemawiającym za wycofaniem taktycznej broni nuklearnej była kwestia zapobiegania proliferacji broni nuklearnej. W klimacie stworzonym wokół tzw. agendy praskiej (wizji świata bez broni nuklearnej prezydenta Obamy, na- 
kreślonej w Pradze w kwietniu 2009 roku) pomysł rezygnacji z nuclear sharing jawił się jako gest o ogromnym znaczeniu symbolicznym, a przy tym niewielkich realnych kosztach (Browne, 2011: 5). Stany Zjednoczone, rezygnując $z$ broni niemającej większego znaczenia militarnego, wysyłałyby czytelny sygnał, że traktują swoje zobowiązania do nuklearnego rozbrojenia poważnie. Krok taki wydawał się rozsądny, biorąc pod uwagę ograniczone możliwości dotychczasowych wariantów B-61 i deklarację prezydenta Obamy, że USA ,nie będą rozwijały nowych głowic nuklearnych ani dążyły do pozyskania nowych możliwości czy zdolności do wykonywania nowych zadań przy pomocy broni nuklearnej" (cytat za: Broad, Sanger, 2016: 1).

USA zrzuciłyby przy tym z siebie odium hipokryzji: trudno było uzasadnić moralne prawo do domagania się od innych państw (przede wszystkim Iranu) porzucenia wysiłków w kierunku zdobycia broni nuklearnej, skoro samemu lekceważyło się zobowiązanie do podjęcia wysiłków dla nuklearnego rozbrojenia. Pamiętać przy tym należy, że traktat o nierozprzestrzenianiu broni nuklearnej z 1968 roku (Treaty on the Non-Proliferation of Nuclear Weapons, w skrócie traktat NPT) nakłada na państwa-strony obowiązek prowadzenia w dobrej wierze rokowań w sprawie skutecznych kroków mających na celu zaprzestanie w najbliższym czasie wyścigu zbrojeń nuklearnych i w sprawie nuklearnego rozbrojenia (NPT Treaty, Art. VI). Jest to zobowiązanie sformułowane w sposób oględny i nieprecyzyjny (np. nie wyznaczono żadnego konkretnego terminu, w jakim takie negocjacje miałyby się odbyć), jednak w kontekście amerykańskich działań w celu zapobiegania proliferacji broni nuklearnej oraz dalekosiężnej wizji nuklearnego rozbrojenia, ewentualne wycofanie taktycznej broni nuklearnej z Europy miałoby znaczącą wymowę symboliczną dowodząc, że USA traktują swoje zobowiązania poważnie i przechodzą od słów do czynów.

Warto dodać, że z punktu zapisów traktatu o nierozprzestrzenianiu broni nuklearnej sama idea nuclear sharing jest mocno wątpliwa. Krytyczne głosy podniosły się m.in. podczas konferencji przeglądowej traktatu NPT w 2010 roku (Sechser, 2015: 4). Artykuł 2 traktatu zabrania bowiem transferu broni nuklearnej z państw nuklearnych do państw nienuklearnych. Co prawda przedstawiciele NATO argumentują, że o żadnym „transferze" nie ma mowy w czasie pokoju, a podczas wojny nie ma możliwości kontrolowania realizacji postanowień NPT, jednakże dokument końcowy konferencji przeglądowej z 1985 roku stanowił, że zobowiązania zaciągnięte w związku z przyjęciem NPT obowiązują „w każdych okolicznościach” (Butcher, Butler, 2010: 33-34). Co więcej, nie jest jasne, jakiego rodzaju wojna miałaby według NATO unieważniać zapisy NPT (zwłaszcza że traktat nie przewiduje takiej opcji).

Jeszcze kilka lat temu powszechne były twierdzenia, że NATO pod względem broni konwencjonalnej jest silniejsze niż jakikolwiek potencjalny przeciwnik (a wręcz, jak twierdził prezydent Clinton, było „najsilniejszym sojuszem w historii”; cytat za: Carpenter, 2001: 25). Podważało to militarny sens posiadania taktycznej broni nuklearnej. Obecnie jednak, biorąc pod uwagę rosnący potencjał Rosji wskutek forsownych reform zapoczątkowanych w 2008 roku, nie jest to już takie oczywiste. Być może więc NATO będzie znowu zmuszone do poszukiwania środków, by zniwelować konwencjonalną przewagę Rosji.

Na losy taktycznej broni nuklearnej decydujący wpływ będzie miał klimat polityczny w Europie. Trudno zaprzeczyć, że wskutek kryzysu na Ukrainie relacje między 
Rosją a NATO są najgorsze od czasu rozpadu Związku Radzieckiego. Tymczasem Rosja posiada w swojej europejskiej części arsenał taktycznej broni nuklearnej o potencjale wielokrotnie przekraczającym potencjał NATO (dokładne dane nie są dostępne, ale szacunki mówią nawet o 4 tysiącach ładunków; Woolf, 2015: 22-23). Rosja tymczasem nawet w okresie tzw. resetu w stosunkach z Zachodem nie przejawiała chęci do rozpoczęcia rozmów na temat porozumienia ograniczającego lub likwidującego tego typu bron. Ewentualna rezygnacja z programu w obecnej sytuacji niewątpliwie odczytana mogłaby być jako oznaka słabości Sojuszu. Kontynuacja programu stanowić będzie wiadomość podkreślająca, że NATO w dalszym ciagu pozostaje sojuszem nuklearnym, nawet jeśli decydują o tym przede wszystkim siły strategiczne, a broń o charakterze taktycznym stanowi tylko skromny dodatek. Świadczy o tym sytuacja z czerwca 2014 roku, gdy NATO postanowiło wysłać Rosji ,subtelny” sygnał nuklearny stanowiący odpowiedź na jej działania na Ukrainie - uczyniono to za pomocą sił strategicznych, przebazowując bombowce do Europy, a nie broni taktycznej (Kristensen, Mount, 2014).

Zasadniczym argumentem za kontynuacją programu (argumentem o charakterze ściśle politycznym, a nie militarnym) jest konieczność zasygnalizowania zaangażowania Stanów Zjednoczonych w zapewnienie bezpieczeństwa swoich europejskich sojuszników. Jakiekolwiek redukcje nuklearnego wymiaru NATO odczytane zostaną jako wstęp do odwrócenia się USA od Europy. Obawy tego rodzaju są szczególnie żywe w państwach bałtyckich, które co prawda nie biorą bezpośredniego udziału w nuclear sharing, ale czują się szczególnie zależne w zakresie bezpieczeństwa od wsparcia NATO i oponują przeciwko jakiemukolwiek zmniejszeniu jego zaangażowania.

$$
* * *
$$

Taktyczna broń nuklearna rozmieszczona w europejskich państwach NATO ma obecnie minimalne znaczenie militarne. Po pierwsze, trudno wyobrazić sobie scenariusz, w ramach którego miałaby ona zostać zastosowana, po drugie, w sytuacji nuklearnego konfliktu w Europie bardziej zasadne byłoby użycie innych środków niż stosunkowo prymitywne bomby lotnicze.

Taktyczną broń nuklearną trudno jednak rozpatrywać w oderwaniu od kontekstu politycznego. Polityczne znaczenie uzbrojenia ilustruje chociażby fakt wystrzelenia przez Rosję rakiet manewrujących na cele w Syrii - działanie kompletnie nieuzasadnione z czysto militarnego punktu widzenia, ale majace ogromne znaczenie jako komunikat polityczny. Broń - a broń nuklearna w szczególności - nie powinna być traktowana tylko instrumentalnie, gdyż równie znacząca jest jej wartość symboliczna. W tym sensie stosowanie, lub nawet tylko posiadanie uzbrojenia, jest rodzajem strategii komunikacyjnej, sygnałem woli politycznej i determinacji (zimnowojenny wyścig zbrojeń nuklearnych jest tego najlepszym przykładem).

Tymczasem NATO ma obecnie problem ze swoją tożsamością. Przekłada się to na trudności w przekuciu ogólnych deklaracji w konkretne przedsięwzięcia (nie mówiąc już o realizacji tych przedsięwzięć). NATO niezmiennie deklaruje, że ,pozostanie sojuszem nuklearnym", ale nie wiadomo, co dokładnie ma to oznaczać w praktyce (Nichols, Stuart, McCausland, 2012: 507). 
Taktyczna broń nuklearna w NATO egzystuje niejako siłą inercji. Nie ma decyzji, żeby z niej zrezygnować, nie ma, żeby ją rozwijać. Trudno nawet o decyzję o zasadniczej przebudowie jej architektury (np. wycofaniu z państw, które kontestuja jej obecność, ewentualnie rozmieszczeniu w innych państwach). Przykładem tego bezwładu decyzyjnego są Niemcy - samoloty Tornado nie są perspektywiczne i jeszcze niedawno zapowiadano ich rychłe wycofanie (obecnie planuje się ich remonty, które pozwola na zachowanie ich w linii do 2025 roku lub nawet dłużej). Nie planuje się jednak ich integracji z najnowszą wersją bomby $B-61$, co stawia pod znakiem zapytania ich przydatność w roli samolotów DCA. Tymczasem nowsze i perspektywiczne samoloty Eurofighter Typhoon w ogóle nie są przeznaczone do tej roli.

Zdecydowano jedynie o ograniczonej modernizacji bomb B-61 i była to decyzja USA, a nie NATO. Nie rozważa się jednak rozwijania taktycznej broni nuklearnej o większych możliwościach z militarnego punktu widzenia, np. rakiet manewrujących w rodzaju francuskiej ASMP-A czy też rakiet balistycznych na wzór rosyjskiego Iskandera (który co prawda przenosi głowicę konwencjonalną, ale Rosjanie nigdy nie wykluczali opracowania wersji z głowicą nuklearna). Tego typu systemy miałyby znacznie większe militarne możliwości niż bomby lotnicze. Ich rozwój wymagałby jednak decyzji, popartej przekonaniem o militarnym znaczeniu taktycznej broni nuklearnej.

Symptomatyczna jest ambiwalentna postawa Niemiec. Państwo to, najsilniejsze politycznie, gospodarczo i (choć tu można się spierać) militarnie spośród uczestników nuclear sharing, mogłoby do pewnego stopnia określać kierunek, w którym przedsięwzięcie to ma podażać. Mogłoby, gdyby Niemcy sami potrafili wskazać chociażby własne priorytety w tym zakresie, a tymczasem nie podjęto nawet decyzji czy państwo to w przyszłości będzie posiadało samoloty DCA, czy też nie.

Nawet zmiana sytuacji w zakresie bezpieczeństwa w Europie nie skłoniła europejskich przywódców do przemyślenia kwestii oceny zagrożeń i wypracowania adekwatnych środków. Jeśli zabrakło takiej ogólnej refleksji, trudno mówić o spójnym i jednoznacznym stanowisku względem taktycznej broni nuklearnej. Dominuje tendencja do unikania tematu i odwlekania decyzji. Być może scenariuszem na przyszłość będzie częściowe samorozbrojenie Europy $\mathrm{z}$ taktycznej broni nuklearnej (np. ograniczenie programu do mniejszej liczby państw, bądź nawet skoncentrowanie calej broni w jednej bazie), ale nie wskutek przemyślanej decyzji uwzględniającej kwestie polityczne i militarne, ale w efekcie wykruszenia się samolotów zdolnych ją przenosić.

\section{BIBLIOGRAFIA}

Anderson J. V., Larsen J. A., Holdorf P. M. (2013), Extended Deterrence and Allied Assurance: Key Concept and Current Challenges for U.S. Policy, Institute for National Security Studies, United States Air Force Academy, Colorado.

Antony I., Janssen J. (2010), The Future of Nuclear Weapons in NATO, Stockholm International Peace Research Institute, Stockholm.

Arbman G., Thornton Ch. (2003), Russia's Tactical Nuclear Weapons. Part I: Background and Policy Issues, Swedish Defence Research Agency, Stockholm.

B-61 (2015), Global Security, http://www.globalsecurity.org/wmd/systems/b61.htm (21.01.2016). 
Boniface P. (1998), French Nuclear Weapons Policy After the Cold War, Atlantic Council of the United States, Washington.

Broad W. J., Sanger D. E. (2016), As U.S. Modernizes Nuclear Weapons, 'Smaller'Leaves Some Uneasy, „The New York Times", http://www.nytimes.com/2016/01/12/science/as-us-modernizes-nuclear-weapons-smaller-leaves-some-uneasy.html?_r=0 (2.02.2016).

Browne D. (2011), Current NATO Nuclear Policy, w: Reducing the Role of Tactical Nuclear Weapons in Europe: Perspectives and Proposals on the NATO Policy Debate, (eds.) P. Ingram, O. Meier, Arms Control Association, British American Security Information Council, Washington-London.

Butcher M., Butler N. (2010), NATO nuclear sharing: an anachronistic obstacle to muclear disarmament and regional security, $\mathrm{w}$ : Beyond arms control: challenges and choices for nuclear disarmament, (ed.) R. Acheson, Reaching Critical Will, New York.

Carpenter T. G. (2001), NATO's Search for Relevance, w: NATO after Fifty Years, (eds.) S. V. Papacosma, S. Kay, M. R. Rubin, Scholarly Resources, Wilmington.

Childs N. (2012), Europe, NATO's Tactical Nuclear Conundrum, and Public Debate: Be Careful What You Wish For, w: Tactical Nuclear Weapon and NATO, (eds.) T. Nichols, D. Stuart, J. D. McCausland, U.S. Army War College, Carlisle.

Czulda R. (2013), Taktyczna broń jadrowa w Europie, „Nowa Technika Wojskowa”, nr 6.

Czulda R. (2014), NATO Tactical Nuclear Weapons in Europe - towards Modernisation or Withdrawal?, „Baltic Security \& Defence Review”, Vol. 17, Issue 2.

Faradori P. (2013), Debating the last remaining case of the forward deployment of nuclear weapons, w: Tactical Nuclear Weapons and Euro-Atlantic Security. The future of NATO, (ed.) P. Faradori, Abingdon.

Ingram P., Kimball D. G., Meier O. (2011), Introduction, w: Reducing the Role of Tactical Nuclear Weapons in Europe: Perspectives and Proposals on the NATO Policy Debate, (eds.) P. Ingram, O. Meier, Arms Control Association, British American Security Information Council, Washington-London.

Kamieński Ł. (2009), Technologia i wojna przyszlości. Wokót nuklearnej i informacyjnej rewolucji w sprawach wojskowych, Kraków.

Kamp K.-H., Remkes R. C. N. (2011), Options for NATO Nuclear Sharing Arrangements, w: Reducing Nuclear Risks in Europe: A Framework for Action, (eds.) S. Andreasen, I. Williams, Nuclear Threat Initiative, Washington.

Kibaroglu M. (2011), Turkey, NATO and Nuclear Sharing: Prospects After NATO's Lisbon Summit, w: Reducing the Role of Tactical Nuclear Weapons in Europe: Perspectives and Proposals on the NATO Policy Debate, (eds.) P. Ingram, O. Meier, Arms Control Association, British American Security Information Council, Washington-London.

Kopeć R. (2014), Strategie nuklearne w okresie pozimnowojennym, Kraków.

Kristensen H. (2013), US Navy Instruction Confirms Retirement of Nuclear Tomahawk Cruise Missile, Federation of American Scientists Strategic Security Blog, http://fas.org/blogs/security/2013/03/tomahawk (26.01.2016).

Kristensen H. M., Mount A. (2014), Why NATO should eliminate its tactical nukes, despite Russian belligerence, „Bulletin of the Atomic Scientists”, http://thebulletin.org/why-nato-shouldeliminate-its-tactical-nukes-despite-russian-belligerence 7415 (2.02.2016).

Kuźniar R. (2005), Polityka i sila, Studia strategiczne - zarys problematyki, Wydawnictwo Scholar, Warszawa.

Laird R. F. (2000), French Nuclear Forces in the 1980 s and 1990s, Center for Naval Analyses, Alexandria. 
Meattig T. (2008), Tactical Nuclear Weapons in Germany: Time to Withdrawal?, Nuclear Threat Initiative, http://www.nti.org/analysis/articles/tactical-nuclear-weapons-germany/ (3.02.2016).

Medalia J. (2006), ,Bunker Busters”: Robust Nuclear Earth Penetrator Issues, FY2005-FY2007, Congressional Research Service, Washington.

Millot M. D. (1997), Facing the Emerging Reality of Regional Nuclear Adversaries, w: American Defense Policy, (eds.) P. L. Hays, B. J. Vallance, A. R. Van Tassel, Baltimore.

Murdock C. A., Yeates J. (2007), Exploring the Nuclear Posture Implications of Extended Deterrence and Assurance, Center for Strategic and International Studies, Washington.

Narang V. (2014), Nuclear Strategy in the Modern Era. Regional Powers and International Conflict, Princeton.

Neuneck G. (2012), European and German Perspectives, w: Tactical Nuclear Weapon and NATO. (eds.) T. Nichols, D. Stuart, J. D. McCausland, U.S. Army War College, Carlisle.

Nichols T., Stuart D., McCausland J. D. (2012), Summing up and issues for the future, w: Tactical Nuclear Weapon and NATO, (eds.) T. Nichols, D. Stuart, J. D. McCausland, U.S. Army War College, Carlisle.

Norris R. S., Arkin W. M. (2000), French and British Nuclear Forces, „Bulletin of Atomic Scientists”, No. $56 / 5$.

Pifer S. (2011), The United States, NATO's Strategic Concept, and Nuclear Issues, w: Reducing the Role of Tactical Nuclear Weapons in Europe: Perspectives and Proposals on the NATO Policy Debate, (eds.) P. Ingram, O. Meier, Arms Control Association, British American Security Information Council, Washington-London.

Rühl L. (2005), The future of US tactical nuclear weapons in Germany and NATO and implications of a draw-down for other nonprolvferation issues, contribution to the Aspen Berlin conference on Germany and Nuclear Nonproliferation, http://www.npolicy.org/article_file/The_future of US tactical nuclear weapons in Germany and NATO and implications of a drawdown for_other_nonproliferation_issues.pdf (2.02.2016).

Schulte P. (2012), Tactical Nuclear Weapons in NATO and Beyond: A Historical and Thematic Examination, w: Tactical Nuclear Weapon and NATO, (eds.) T. Nichols, D. Stuart, J. D. McCausland, U.S. Army War College, Carlisle.

Sechser T. S. (2015), Sharing the Bomb: Nonprolfferation, Deterrence, and Foreign Nuclear Deployments, University of Virginia, Charlottesville.

Stein A. (2012), Turkey and Tactical Nuclear Weapons: A Political Love Affair, EDAM Centre for Economics and Foreign Policy Studies, Istanbul.

Tannenwald N. (2007), The Nuclear Taboo, The United States and the Non-Use of Nuclear Weapon since 1945, Cambridge.

Tertrais B. (2004), 'Destruction Assurée': The Origins and development of French Nuclear Strategy, 1945-1981, w: Getting MAD: Nuclear Mutual Assured Destruction, its Origins and Practice, (ed.) H. D. Sokolsky, Strategic Studies Institute, U.S. Army War College, Carlisle.

Tertrais B. (2007), A Comparison between US, UK and French Nuclear Policy, Centre d'Etudes de Relations Internationales, Paris.

Treaty on the Non-Prolfferation of Nuclear Weapons, International Atomic Energy Agency, Art. VI.

Weitz R. (2012), The Historical Context, w: Tactical Nuclear Weapon and NATO, (eds.) T. Nichols, D. Stuart, J. D. McCausland, U.S. Army War College, Carlisle.

Wilson L. (2014), Between the Lines: The B61 Life Extension Program, w: Nuclear Scholar Initiative: A Collection of Papers from the 2013 Nuclear Scholar Initiative, (ed.) S. Weiner, Center for Strategic and International Studies, Washington.

Woolf A. F. (2015), Nonstrategic Nuclear Weapon, Congressional Research Service, Washington. 


\title{
STRESZCZENIE
}

Taktyczna broń nuklearna, będąca w czasie zimnej wojny dominującym pod względem liczebnym rodzajem broni nuklearnej, egzystuje obecnie na marginesie strategicznej refleksji. Celem artykułu jest przybliżenie tematyki taktycznej broni nuklearnej funkcjonującej w europejskich państwach NATO (chociaż jest to przede wszystkim broń amerykańska). Artykuł definiuje pojęcie taktycznej broni nuklearnej, a także prezentuje rys historyczny tego rodzaju broni, ze szczególnym uwzględnieniem powodów jej rozwoju w czasie zimnej wojny przez państwa zachodnie. Osią artykułu jest realizowany w ramach NATO program nuclear sharing (chociaż opisana zastała także francuska broń niestrategiczna) - jego założenia, obeeny status oraz perspektywy, w tym kontrowersje związane z przyszłością taktycznej broni nuklearnej w Europie.

Slowa kluczowe: taktyczna broń nuklearna, nuklearne współdzielenie, odstraszanie rozszerzone, traktat NPT

\section{TACTICAL NUCLEAR WEAPONS IN EUROPE}

\begin{abstract}
Tactical nuclear weapons were quantitatively a dominant class of nuclear weapons in the Cold War. However, currently, they stay on the margin of strategic thinking. The aim of the article is to provide a reader with an insight into the issues related to tactical nuclear weapons in the European NATO countries (however, they are primarily American weapons). The article defines the term ,tactical nuclear weapons" and provides an overview of these weapons. It stresses the reasons of their development by the Western countries in the Cold War. The paper focuses on the nuclear sharing NATO program (but French non-strategic weapons are also mentioned) - its principles, current status and prospects, including controversies around the future of tactical nuclear weapons in Europe.
\end{abstract}

Key words: tactical nuclear weapons, nuclear sharing, extended deterrence, NPT treaty 